\title{
Enzyme-assisted aqueous extraction of Kalahari melon seed oil: optimization using response surface methodology
}

\begin{abstract}
Enzymatic extraction of oil from Kalahari melon seeds was investigated and evaluated by response surface methodology (RSM). Two commercial protease enzyme products were used separately: Neutrase ${ }^{\circledR} 0.8$ L and Flavourzyme ${ }^{\circledR} 1000$ L from Novozymes (Bagsvaerd, Denmark). RSM was applied to model and optimize the reaction conditions namely concentration of enzyme (20ï $50 \mathrm{~g} \mathrm{kgl̄} 1$ of seed mass), initial $\mathrm{pH}$ of mixture ( $\mathrm{pH} 5 \mathrm{i} 9$ ), incubation temperature $\left(40 \mathrm{i} 60{ }^{\circ} \mathrm{C}\right)$, and incubation time $(12 \mathrm{i} 36 \mathrm{~h})$. Well fitting models were successfully established for both enzymes: Neutrase $0.8 \mathrm{~L}(\mathrm{R} 2=0.9410)$ and Flavourzyme $1000 \mathrm{~L}$ (R $2=0.9574)$ through multiple linear regressions with backward elimination. Incubation time was the most significant reaction factor on oil yield for both enzymes. The optimal conditions for Neutrase $0.8 \mathrm{~L}$ were: an enzyme concentration of $25 \mathrm{~g} \mathrm{kgī} 1$, an initial $\mathrm{pH}$ of 7 , a temperature at $58{ }^{\circ} \mathrm{C}$ and an incubation time of $31 \mathrm{~h}$ with constant shaking at 100 $\mathrm{rpm}$. Centrifuging the mixture at $8,000 \mathrm{~g}$ for $20 \mathrm{~min}$ separated the oil with a recovery of 68.58 $\pm 3.39 \%$. The optimal conditions for Flavourzyme $1000 \mathrm{~L}$ were enzyme concentration of $21 \mathrm{~g}$ $\mathrm{kg} \overline{1} 1$, initial $\mathrm{pH}$ of 6 , temperature at $50{ }^{\circ} \mathrm{C}$ and incubation time of $36 \mathrm{~h}$. These optimum conditions yielded a $71.55 \pm 1.28 \%$ oil recovery.
\end{abstract}

Keyword: Enzyme-assisted aqueous extraction; Kalahari melon seed oil; Optimization; Response surface methodology; Central composite design (CCD); Neutrase 0.8 L; Flavourzyme $1000 \mathrm{~L}$ 